\title{
EFFECTIVENESS OF RAPE PROTECTION AGAINST PESTS IN THE YEARS 2006-2009 IN POLAND
}

\author{
Felicyta Walczak ${ }^{1}$, Maria Golinowska², Anna Tratwal ${ }^{*}$, Andrzej Bandyk \\ ${ }^{1}$ Institute of Plant Protection - National Research Institute \\ Władysława Węgorka 20, 60-318 Poznań, Poland \\ ${ }^{2}$ Wrocław University of Environmental and Life Sciences \\ Norwida 25/27, 50-275 Wrocław, Poland
}

Received: February 22, 2012

Accepted: March 27, 2012

\begin{abstract}
Long-term research on the intensification of economically significant pests in rape cultivation has been conducted by the Plant Protection Institute - National Research Institute (PPI - NRI) Poznań, Poland. This research has allowed for a determination of the economic effectiveness of chemical plant protection against pests. The research was conducted during the 2006-2009 time period. Results showed that the economic effectiveness expressed in approximate profitability indexes $E_{1}$ and $E_{2}$ in rape cultivation in Poland was diversified. The values were influenced by the selling prices of rape, intensification of pest occurrence, and yield. To prevent losses in yields, chemical crop protection has been implemented. In 2006, rape underwent an average of two treatments against pests: one against diseases and one reducing weed infestation. The primary rape-attacking pests from 2006 to 2009 were: rape pollen beetle (Meligethes aeneus F.), cabbage stem weevil (Ceutorhynous quadridenz Penz), cabbage seed weevil (Ceutrohynorus assimillis Payk.) and pod gall midge (Dasyneura brassicae Winn.).
\end{abstract}

Key words: rape pests, control effectiveness, monitoring

\section{INTRODUCTION}

Rape is currently the primary and most important oil plant cultivated in Poland. The economic significance of rape cultivation is reflected in the increased cultivation area and yields (Table 1). In 2009, the cultivation area amounted to 769,000 ha and was twice as larger as in the 1990s. Between 1946 and 2009, the rape yields increased from $7.4 \mathrm{dt} /$ ha to $30.8 \mathrm{dt} / \mathrm{ha}$. The cultivation area for rape in the world in 1997, was $24.2 \mathrm{mln}$ ha, out of which $16.2 \%$ was in Europe. The mean yield in the world was $14.5 \mathrm{dt} /$ ha. The highest 1997 mean yield was observed in Europe and amounted to $26.5 \mathrm{dt} / \mathrm{ha}$ (FAO 1997). In 2008 and 2009, members of the European Union cultivated rape on 6,199 ha and 6,485 ha, respectively. Poland accounted for $12.6 \%$ of that area in 2008 and $12.5 \%$ in 2009 . The most significant rape producers in the European Union are Germany, France and Great Britain.

The climate for rape cultivation in Poland is less favorable than in the above noted countries. There were years in Poland when big parts of the rape acreage had to be plowed after wintering. Recently, producers have been much more interested in rape cultivation due to a different use of rape seeds. Rape is now seen not only as edible fat, but also as a component used to produce biofuel. Spatial diversity of the area and yields in 2009 are shown on figure 1. A bigger concentration in rape cultivation is present in south-western Poland, both in terms of cultiva- tion areas and yields. In recent years the biggest producer of rape has been the Wielkopolskie province (Table 2). In regions with a big rape concentration in the sowing structure, amounting to $30 \%$ of arable lands, it is easy to provide conditions favorable for increased occurrence of pests which destroy the crops. To prevent losses in yields, chemical crop protection is implemented. In 2006, rape underwent an average of two treatments against pests, one against diseases, and one reducing weed infestation. An average of four protection treatments were implemented.

The primary rape-attacking pests in the years 20062009 were: rape pollen beetle (Meligethes aeneus F.), cabbage stem weevil (Centorhynous quadridenz Penz), cabbage seed weevil (Centrohynorus assimillis Payk.) and pod gall midge (Dasyneura brassicae Winn.). The aforementioned pests can cause significant losses in yields, especially in regions where the cultivation is intensive (big sums of money spent on fertilizers and crop protection chemicals) and in regions where rape constitutes more than $10 \%$ of the arable land sowed. In Poland, these types of regions with the accompanying pests can be found in the west and south-west.

The aim of the study was to determine the effectiveness of chemical protection of rape against economically significant pests in the years 2006-2009. 
Table 1. Rape and turnip-like rape production in Poland in the years 1946-2009

\begin{tabular}{|c|c|c|c|c|}
\hline No. & Years & Area per 1,000 ha & Yield [dt/ha] & Harvest in 1,000 $\mathrm{t}$ \\
\hline 1 & $1946-1950$ & 85 & 7.4 & 108 \\
2 & $1951-1955$ & 151 & 10.7 & 108 \\
3 & $1956-1960$ & 101 & 14.3 & 323 \\
4 & $1961-1965$ & 223 & 17.9 & 516 \\
5 & $1965-1970$ & 279 & 18.4 & 557 \\
6 & $1971-1975$ & 304 & 18.7 & 637 \\
7 & $1976-1980$ & 327 & 20.6 & 693 \\
9 & $1981-1985$ & 329 & 25.3 & 906 \\
10 & $1986-1990$ & 511 & 20.5 & 847 \\
11 & $1991-1995$ & 427 & 20.7 & 1,178 \\
12 & $1996-2000$ & 352 & 20.6 & 1,652 \\
13 & $2001-2005$ & 479 & 26.5 & 2,130 \\
14 & 2006 & 624 & 26.7 & 2,106 \\
\hline 15 & 2007 & 797 & 27.3 & 2,497 \\
\hline
\end{tabular}

Source: Statistical Yearbook

Table 2. Ranking of provinces by cultivation area and rape yields in the years 2006-2009

\begin{tabular}{|c|c|c|c|c|c|c|c|c|}
\hline \multirow{3}{*}{ Province } & \multicolumn{4}{|c|}{ Area } & \multicolumn{4}{|c|}{ Yield } \\
\hline & \multicolumn{8}{|c|}{ years } \\
\hline & 2006 & 2007 & 2008 & 2009 & 2006 & 2007 & 2008 & 2009 \\
\hline 1. Dolnośląskie & 2 & 2 & 1 & 3 & 2 & 4 & 3 & 3 \\
\hline 2. Kujawsko-pomorskie & 4 & 4 & 3 & 2 & 4 & 2 & 2 & 2 \\
\hline 3. Lubelskie & 8 & 8 & 8 & 8 & 8 & 8 & 8 & 9 \\
\hline 4. Lubuskie & 10 & 10 & 10 & 9 & 10 & 10 & 9 & 8 \\
\hline 5. Łódzkie & 12 & 12 & 12 & 12 & 13 & 12 & 12 & 12 \\
\hline 6. Małopolskie & 16 & 16 & 15 & 16 & 15 & 15 & 15 & 15 \\
\hline 7. Mazowieckie & 9 & 9 & 9 & 10 & 9 & 9 & 10 & 10 \\
\hline 8. Opolskie & 5 & 5 & 5 & 5 & 5 & 5 & 5 & 5 \\
\hline 9. Podkarpackie & 13 & 13 & 13 & 13 & 12 & 13 & 13 & 13 \\
\hline 10. Podlaskie & 15 & 15 & 16 & 15 & 16 & 16 & 16 & 16 \\
\hline 11. Pomorskie & 7 & 7 & 7 & 7 & 6 & 6 & 6 & 6 \\
\hline 12. Śląskie & 11 & 11 & 11 & 11 & 11 & 11 & 11 & 11 \\
\hline 13. Świętokrzyskie & 14 & 14 & 14 & 14 & 14 & 14 & 14 & 14 \\
\hline 14. Warmińsko-mazurskie & 6 & 6 & 6 & 6 & 7 & 7 & 7 & 7 \\
\hline 15. Wielkopolskie & 3 & 1 & 2 & 1 & 1 & 1 & 1 & 1 \\
\hline 16. Zachodniopomorskie & 1 & 3 & 4 & 4 & 3 & 3 & 4 & 4 \\
\hline
\end{tabular}




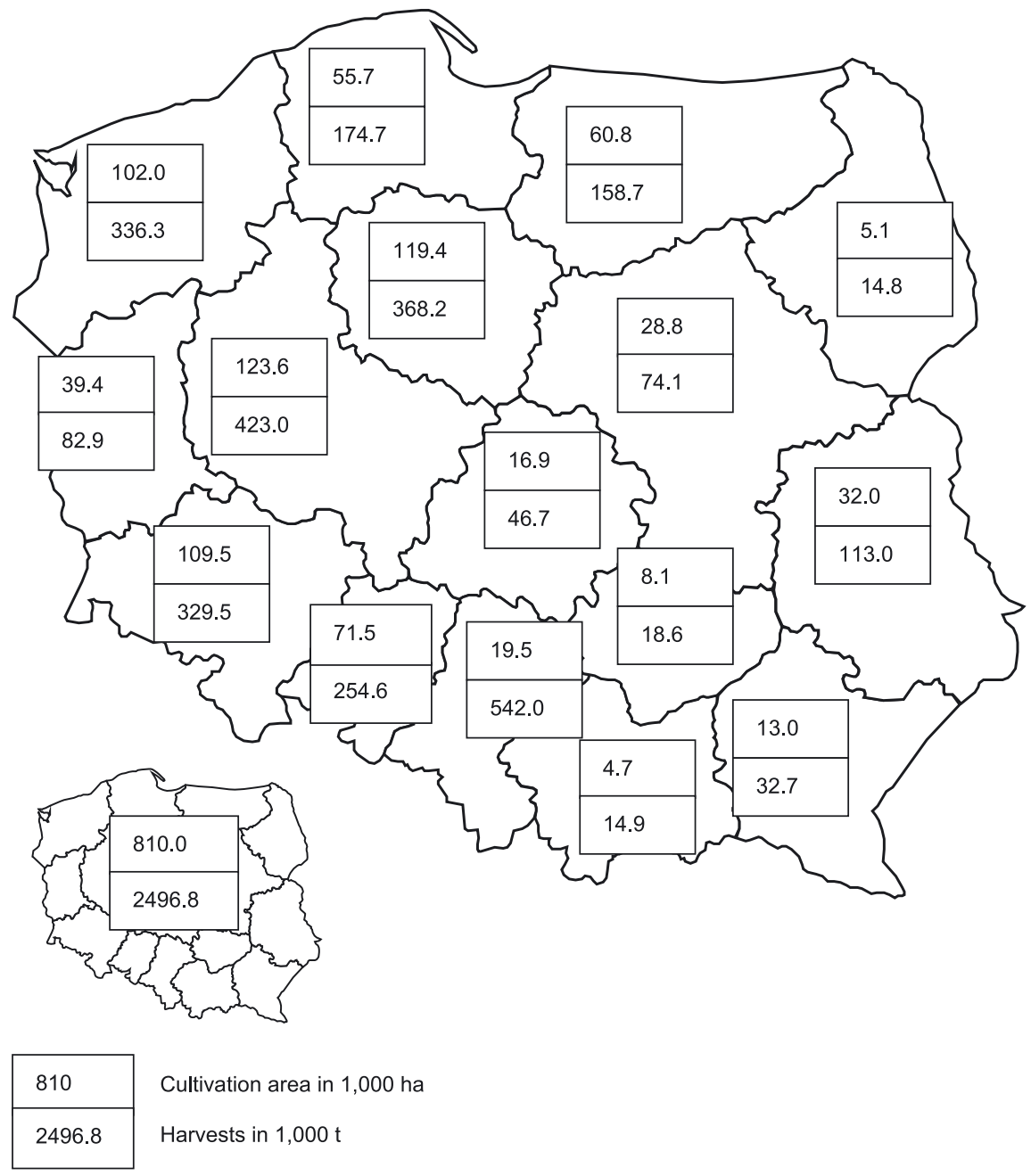

Fig. 1. Rape cultivation area and harvests in 2009

\section{MATERIALS AND METHODS}

The research material for this study came primarily from secondary sources, including materials from the Department of Pest Forecasting Methods and the Economics of Plant Protection, Institute of Plant Protection - National Research Institute (IPP - NRI). These departments study the phytosanitary condition of plants in Poland and carry out nation-wide monitoring of the damage potential of economically significant pests. The monitoring consists of conducting annual pest observations by the researchers of the Plant Health and Seed Inspection Service (PH and SIS), according to the methods developed by research workers from the Department of Pest Forecasting Methods and the Economics of Plant Protection, IPP - NRI with the aim of determining the harmfulness of pests in the entire country (Walczak 2006, 2008, 2009, 2010; Jajor et al. 2008). The compiled data have allowed for a presentation of the changes relating to the intensification of the damage potential, regional distribution, and spreading of rape pests and diseases

The research implemented purposeful selection of rape pests and insecticides recommended for pest control, and Decis 2.5 EC and Fastac 100 EC were chosen. Current prices of plant and rape protection chemicals were also considered.
The research material was developed according to a horizontal analysis as well as a horizontal and comparative analysis. The effectiveness of rape protection against pests was determined using approximate indexes of profitability $E_{1}$ and $E_{2}$ (Golinowska 2002).

Index $E_{1}$ specifies the $\mathrm{dt}$ number of the protected product balancing the actual costs of the treatment. Index $E_{2}$ shows the percentage of yield that needs to be allocated to cover the costs of the protection treatment.

$$
\begin{gathered}
E_{1}=\frac{K_{z}}{C} \\
E_{2}=\frac{E_{1} \cdot 100}{p}
\end{gathered}
$$

where:

$K_{z}$ - treatment costs including the cost of chemicals and application thereof,

C - price of $1 \mathrm{dt}$ of rape (2006 - 44.80 PLN/dt; 2007 - 93.40

PLN/dt; 2008 - 95.70 PLN/ha; 2009 - 108.24 PLN/dt),

$p$ - rape yield in $\mathrm{dt} / \mathrm{ha}$.

The calculation of pest control costs in rape cultivation used the prices of two plant protection chemicals: Decis 2.5 EC and Fastac 100 EC, which are presented in table 3. 
Table 3. Prices of insecticides

\begin{tabular}{|l|c|c|c|}
\hline \multirow{2}{*}{ Specification } & \multicolumn{3}{c|}{ Years } \\
\cline { 2 - 4 } & 2006 & 2007 & 2008 \\
\hline Unit price PLN & & 145.00 & 160.00 \\
Decis 2.5 EC & 223.00 & 120.00 & 124.00 \\
Fastac 100 EC & 118.00 & & 13.00 \\
\hline Insecticide costs PLN/ha & & 36.00 & 40.00 \\
Decis 2.5 EC & 56.00 & 14.40 & 14.90 \\
Fastac 100 EC & 14.00 & & 28.00 \\
\hline
\end{tabular}

Source: own research; PLN - Polish currency

The actual costs of a protection treatment consist of the costs of the plant protection chemical and the costs of application thereof (Golinowska 2002). The costs of a onetime application of the plant protection chemicals in rape cultivation were estimated and it was noted that in 2006 they were 46.00 PLN/ha, in 2007 they were 72.00 PLN/ha, in 2008 they were 54.00 PLN/ha and in 2009 they were $50.00 \mathrm{PLN} / \mathrm{ha}$.

Issues related to the industrial-scale pest control treatments in rape in Poland, have been studied by: Pałosz (1988), Golinowska (1991), Mrówczyński (2003), Kelm (2000), Mrówczyński i Pruszyński (2006).

\section{RESULTS AND DISCUSSION}

Damage potential of rape-damaging pests selected for the research in the years 2006-2009 is distributed in the following manner:
Rape pollen beetle (M. aeneus) - in the last four years its harmfulness exceeded the mean value from the years 2006-2009 (calculated based on a nationwide average, amounting to $9.30 \%$ of damaged flower buds). It was observed in the regions of northern and southern Poland, i.e. in the Warmińsko-Mazurskie, Zachodniopomorskie, Śląskie and Pokarpackie provinces (Fig. 2). In the year 2006, more pests were observed in the following remote sites of PH and SIS: Sieradz (Łódzkie province), where a $40 \%$ damage of winter rape flower buds was noted, and Przemyśl, with a 35\% damage. In the year 2008, the most pests were observed in the Wegorzewo remote site (Warmińsko-Mazurskie province), with a 55\% damage, and in the year 2009, the Pomorskie province had $41 \%$ noted damage.

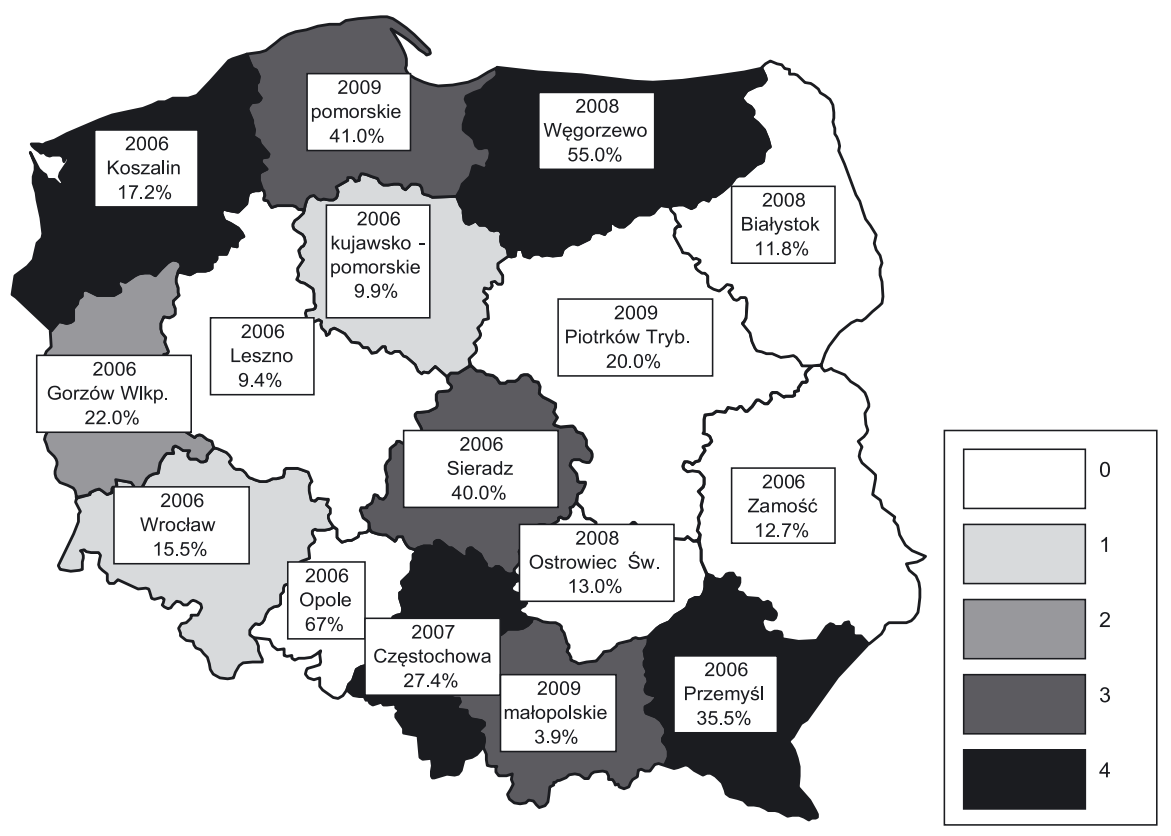

0. Damage potential below $9.30 \%$ of damaged flower buds in the years 2006-2009.

1. Damage potential above $9.30 \%$ of damaged flower buds in 1 year of the years 2006-2009.

2. Damage potential above $9.30 \%$ of damaged flower buds in 2 years of the years 2006-2009.

3. Damage potential above $9.30 \%$ of damaged flower buds in 3 years of the years 2006-2009.

4. Damage potential above $9.30 \%$ of damaged flower buds in 4 years of the years 2006-2009. 


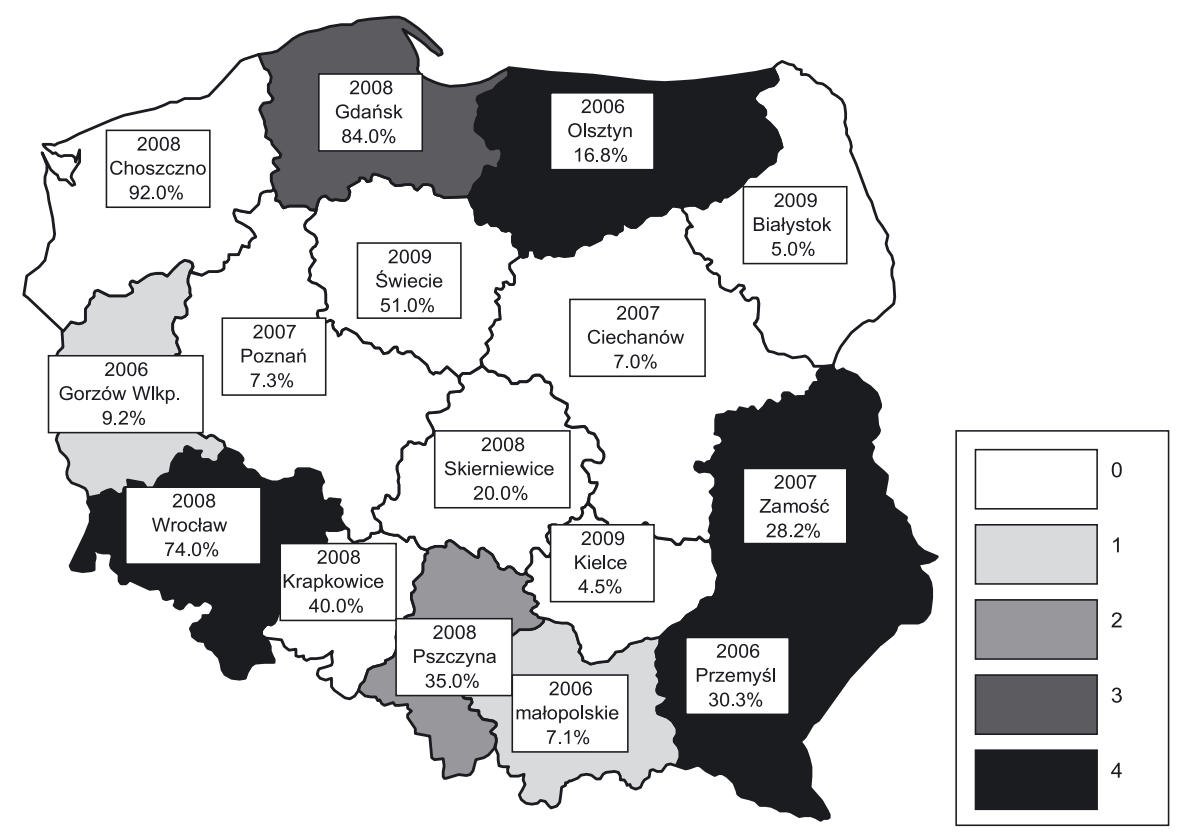

0. Damage potential below $6.60 \%$ of damaged flower buds in the years 2006-2009.

1. Damage potential above $6.60 \%$ of damaged flower buds in 1 year of the years 2006-2009.

2. Damage potential above $6.60 \%$ of damaged flower buds in 2 years of the years 2006-2009.

3. Damage potential above $6.60 \%$ of damaged flower buds in 3 years of the years 2006-2009.

4. Damage potential above $6.60 \%$ of damaged flower buds in 4 years of the years 2006-2009.

Fig. 3. Cabbage stem weevil (C. quadridens) in the winter rape crops from 2006 to 2009

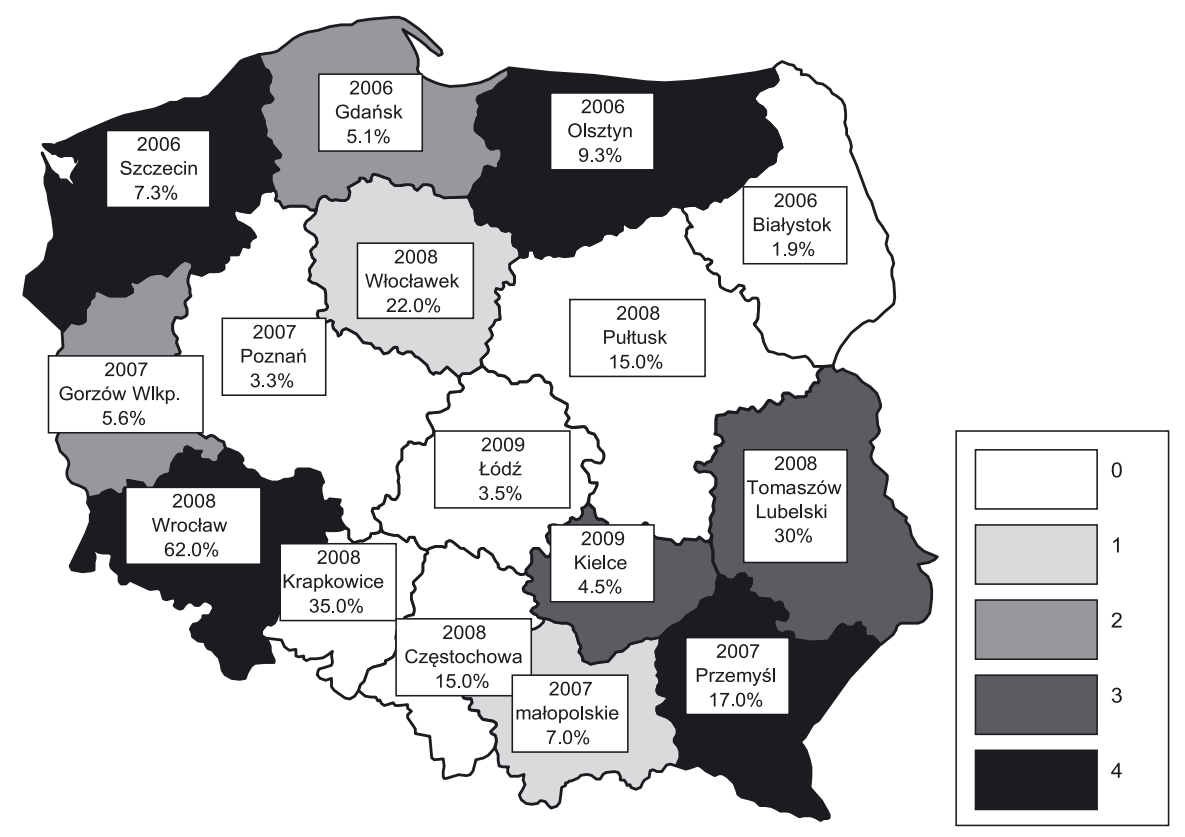

0. Damage potential below $3.68 \%$ of damaged flower buds in the years 2006-2009.

1. Damage potential above $3.68 \%$ of damaged flower buds in 1 year of the years 2006-2009.

2. Damage potential above $3.68 \%$ of damaged flower buds in 2 years of the years 2006-2009.

3. Damage potential above $3.68 \%$ of damaged flower buds in 3 years of the years 2006-2009.

4. Damage potential above $3.68 \%$ of damaged flower buds in 4 years of the years 2006-2009.

Fig. 4. Rape stem weevil (C. napi) in the winter rape crops for the years 2006-2009 
Cabbage stem weevil (Ceutorhynchus quadridens Panz.) - from 2006 to 2009 the average damage potential of this pest was $6.60 \%$ of damaged winter rape plants (Fig. 3). In the south-western (Podkarpackie, Lubelskie) and southeastern (Dolnośląskie) provinces annually, from 2006 to 2009, one could observe more than the average amount of damage. During the analyzed years, the biggest intensification of the occurrence of the pest in the country (over $35.0 \%$ of damaged plants) was noted in the year 2008, at the following PH and SIS remote sites: Choszczno (Zachodniopomorskie province), with a $92 \%$ damage to the winter rape plants, Gdańsk (Pomorskie province), with $84 \%$, Wrocław (Dolnośląskie province), with $74 \%$, Pszczyna (woj. Śląskie), with 35\%, and in the year 2009 in Świecie (Kujawsko-Pomorskie province), with 51\%.

Rape stem weevil (Ceutorhynchus napi Gyll.) - the mean harmfulness calculated from the nationwide mean values from 2006 to 2009 , was $3.68 \%$ of the damaged winter rape plants (Fig. 4). For all the analyzed years, the regions where the damage was bigger than the determined mean value are the provinces located in: the north-east (Warmińsko-azurskie province), north-west (Zachodniopomorskie province), south-west (Dolnośląskie) and south-east (Podkarpackie province). During the analyzed years it was in 2008 that the most damage was done by the rape at stem weevil to winter rape the following $\mathrm{PH}$ and SIS remote sites: in the Dolnośląskie province, Wrocław (63\% of damaged plants), in the Opolskie province, Krapkowice (35\%), in the Lubelskie province, Tomaszów
Lubelski (30\%) and in the Kujawsko-pomorskie province, Włocławek (22\%).

Cabbage seed weevil (C. assimillis) - from 2006 to 2009, an average of $3.90 \%$ shucks of winter rape were damaged (Fig. 5). In the analyzed years, more than the average number of this weevil were noted during a three year period in the following south-eastern provinces: Podkarpackie, Lubelskie, Śląskie and Kujawsko-Pomorskie. The cabbage seed weevil was a bigger threat to winter rape crops in 2008, at the following PH and SIS remote sites: Złotów (wielkopolskie province), $48 \%$ of winter rape shucks were damaged, Drawsko Pomorskie (Zachodniopomorskie province), 40\%, Lubaczów (Podkarpackie province), 38\% and Puławy (Lubelskie province), 34\%.

Pod gall midge (D. brassicae) - the average harmfulness in the country from 2006 to 2009 was seen as $4.15 \%$ damaged winter rape shucks (Fig. 6). From 2006 to 2009, the calculated mean value was exceeded three times in the following provinces in the north: Podlaskie, Pomorskie and Kujawsko-Pomorskie. The pest was a bigger threat to winter rape crops in 2009, in western Poland at the following PH and SIS remote sites: Piła (Wielkopolskie province) and Wąbrzeźno (Kujawsko-Pomorskie province), with $35 \%$ of damaged shucks, Lubiń (Dolnośląskie province), 30\%, Goleniów (Zachodniopomorskie province), 25\% and Strzelce Krajeńskie (Lubuskie province), $23 \%$ and in eastern Poland in Tomaszów Lubelski (Lubelskie province), $16 \%$.

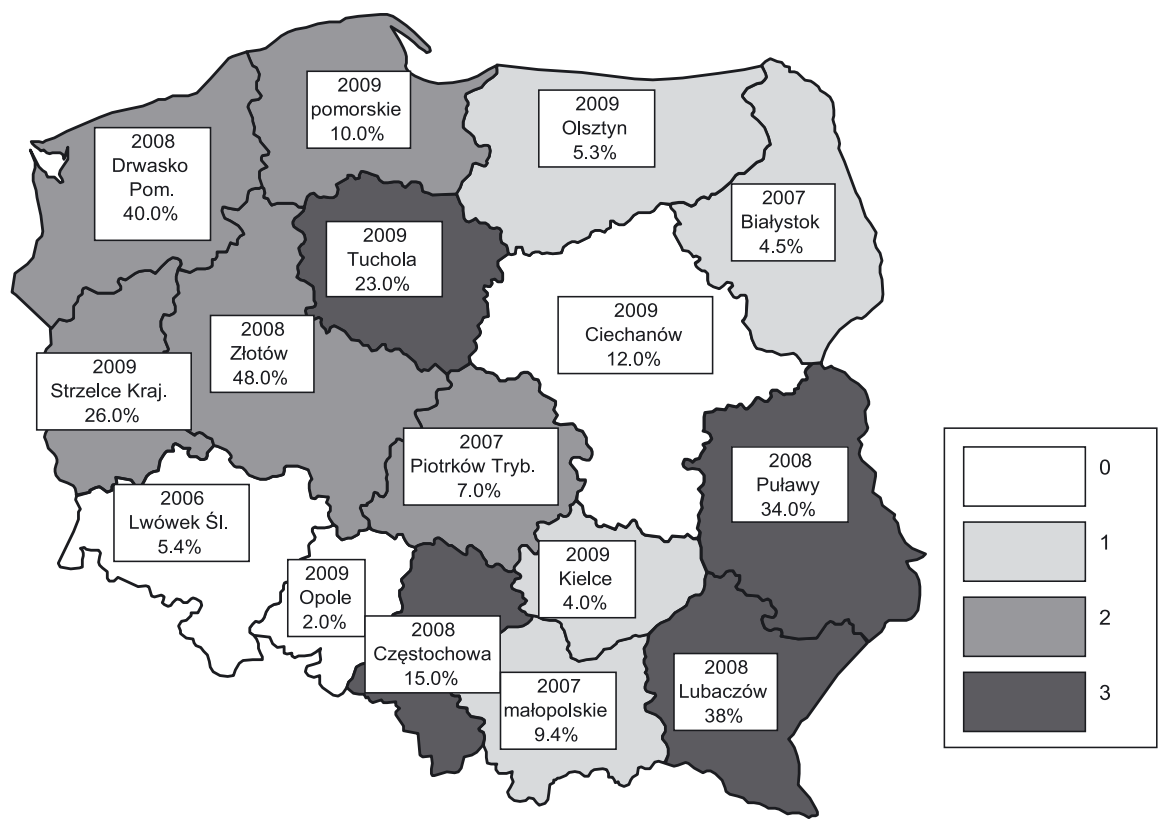

0. Damage potential below 3.90\% of damaged flower buds in the years 2006-2009.

1. Damage potential above $3.90 \%$ of damaged flower buds in 1 year for the years 2006-2009.

2. Damage potential above 3.90\% of damaged flower buds in 2 years for the years 2006-2009.

3. Damage potential above $3.90 \%$ of damaged flower buds in 3 years for the years 2006-2009.

Fig. 5. Cabbage seed weevil (C. assimilis) to the winter rape crops for the years 2006-2009 


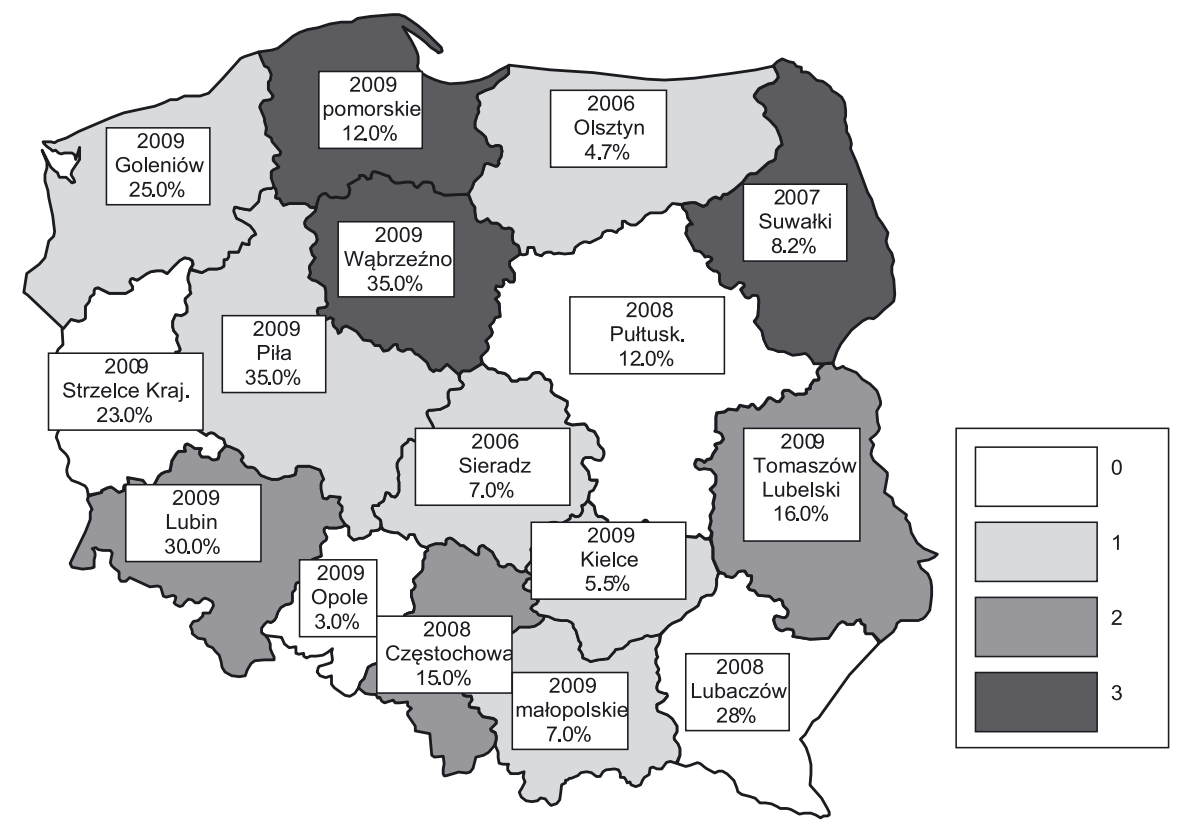

0. Damage potential below $4.15 \%$ of damaged flower buds in the years 2006-2009.

1. Damage potential above $4.15 \%$ of damaged flower buds in 1 year for the years 2006-2009.

2. Damage potential above $4.15 \%$ of damaged flower buds in 2 years for the years 2006-2009.

3. Damage potential above $4.15 \%$ of damaged flower buds in 3 years for the years 2006-2009.

Fig. 6. Pod gall midge (D. brassicae) in winter rape crops for the years 2006-2009

Work area for pest control in rape cultivation in 2006 amounted to $1 \mathrm{mln}$ ha. In the following years, the work area for the pest control was dependent on the cultivation area, which in that period was increasing regularly, from 624,000 ha to 810,000 ha (Table 1). Average doses of the chemical applied are presented in table 3, and the costs and application of the chemical in table 4 . From the economic standpoint, relevant tasks related to chemical pest control in rape cultivation have become significant in south-western Poland, where the rape's share in the sowing structure is large (more than $10 \%$ of arable lands).
Insecticides Decis 2.5 EC and Fastac 100 EC are applied when controlling the researched pests and are listed in the plant protection recommendations for the years 2006-2007 and 2009/2010 (Table 3).

In rape cultivation in Poland, an average of two treatments are conducted. Depending on the year and the chemical applied, the cost of one treatment fluctuates between 59 PLN/h and 108 PLN/h (Table 4).

Profitability of a one-time treatment measured by the $\mathrm{dt}$ number of the protected product (rape seeds) for the years 2006-2009 may be considered decent, since there

Table 3. Doses of insecticide for pest control

\begin{tabular}{|c|c|c|c|c|c|}
\hline \multirow{2}{*}{ Insecticides } & \multicolumn{5}{|c|}{ Pests } \\
\cline { 2 - 6 } & rape pollen beetle & $\begin{array}{c}\text { cabbage stem } \\
\text { weevil }\end{array}$ & rape stem weevil & $\begin{array}{c}\text { cabbage seed } \\
\text { weevil }\end{array}$ & pod gall midge \\
\cline { 2 - 6 } & \multicolumn{5}{|c|}{ dose [1/ha] } \\
\hline Decis 2.5 EC & 0.2 & 0.2 & 0.3 & 0.3 & 0.3 \\
Fastac 100 EC & 0.1 & 0.1 & 0.1 & 0.1 & 0.1 \\
\hline
\end{tabular}

Source: own calculations

Table 4. Costs of a one-time treatment and profitability of the treatment

\begin{tabular}{|c|c|c|c|c|}
\hline \multirow{2}{*}{ Specification } & \multicolumn{4}{|c|}{ Years } \\
\cline { 2 - 5 } & 2006 & 2007 & 2008 & 2009 \\
\cline { 2 - 5 } & \multicolumn{4}{|c|}{ Costs of a one-time treatment [PLN/ha] } \\
\hline Decis 2.5 EC & 101 & 108 & 104 & 78 \\
Fastac 100 EC & 59 & 86 & 79 & 65 \\
\hline Decis 2.5 EC & 2.3 & 1.2 & 1.1 & 0.7 \\
Fastac 100 EC & 1.3 & 0.9 & 0.8 & 0.6 \\
\hline
\end{tabular}


Table 5. Percentage of harvest covering the costs of a chemical protection treatment in 2009

\begin{tabular}{|c|c|c|c|c|}
\hline \multirow{3}{*}{ Province } & \multicolumn{4}{|c|}{ Approximate profitability index $E_{2}[\%]$} \\
\hline & \multicolumn{2}{|c|}{ one-time treatment } & \multicolumn{2}{|c|}{ two-time treatment } \\
\hline & Decis $2.5 \mathrm{EC}$ & Fastac $100 \mathrm{EC}$ & Decis $2.5 \mathrm{EC}$ & Fastac $100 \mathrm{EC}$ \\
\hline 1. Dolnośląskie & 3.00 & 2.24 & 6.00 & 4.48 \\
\hline 2. Kujawsko-pomorskie & 2.80 & 2.10 & 5.80 & 4.20 \\
\hline 3. Lubelskie & 3.38 & 2.53 & 6.76 & 5.06 \\
\hline 4. Lubuskie & 2.80 & 2.10 & 5.60 & 4.20 \\
\hline 5. Łódzkie & 3.10 & 2.32 & 6.20 & 4.64 \\
\hline 6. Małopolskie & 3.38 & 2.53 & 4.76 & 5.06 \\
\hline 7. Mazowieckie & 2.95 & 2.21 & 4.90 & 4.42 \\
\hline 8. Opolskie & 3.11 & 2.33 & 6.22 & 4.66 \\
\hline 9. Podkarpackie & 3.81 & 2.86 & 7.62 & 5.72 \\
\hline 10. Podlaskie & 2.96 & 2.22 & 4.92 & 4.44 \\
\hline 11. Pomorskie & 2.90 & 2.17 & 5.80 & 3.34 \\
\hline 12. Śląskie & 3.52 & 2.64 & 7.04 & 5.24 \\
\hline 13. Świętokrzyskie & 3.56 & 2.67 & 7.12 & 5.34 \\
\hline 14. Warmińsko-mazurskie & 3.29 & 2.47 & 6.58 & 4.94 \\
\hline 15. Wielkopolskie & 2.75 & 2.06 & 5.50 & 4.12 \\
\hline 16. Zachodniopomorskie & 2.85 & 2.14 & 5.70 & 4.28 \\
\hline Poland & 2.96 & 2.22 & 5.92 & 4.40 \\
\hline
\end{tabular}

Source: own calculations

has been a downward trend in the approximate profitability index. A significant factor in the value of the index was the selling price of rape, which in the researched period increased from 44.8 PLN/dt in 2006 to $127.76 \mathrm{PLN} / \mathrm{dt}$ in 2009, making it almost three times higher. The prices of production resources (plant protection chemicals, fuel) increased as well, but not by this much. Table 5 shows changes in the approximate profitability index $E_{2}$, which specifies the percent of harvest covering a one-time or two-time treatment of rape pest control in Poland, by provinces, in 2009. Despite a relatively small rape yield, to cover the costs of pest control one had to allocate between $2.06 \%$ and $7.62 \%$ of the harvest, depending on the chemical applied and the region. The provinces of south-western Poland which show high profitability regarding pest control in rape are the following: Opolskie, Dolnośląskie, Wielkopolskie, Zachodniopomorskie, Kujawsko-Pomorskie and Pomorskie.

While analyzing the profitability of a chemical treatment or plant protection treatments, one needs to consider the agrotechnology related issues for each cultivation. The increase of rape in the sowing structure to more than $10 \%$ of arable lands is becoming a significant health problem for plantations. Chemical protection of rape needs to be analyzed from many different standpoints because the pests are not the only cause of the decrease in yields. The costs of rape cultivation on a large farm in 2007 amounted to 1,930 PLN/ha (Kucharski and Golinowska 2009), the average yield of rape was $33 \mathrm{dt} / \mathrm{ha}$, and $1 \mathrm{dt}$ was sold for 125.00 PLN. These figures mean the value of a yield per ha was 4,125 PLN/ha. That value needs to be increased by the value of a direct subsidy of $596.00 \mathrm{PLN} / \mathrm{ha}$, which will increase the global production expressed in zł per 1 ha of cultivation to 4,271 PLN. The direct surplus from
1 ha of rape cultivation per farm in 2007 amounted to 2,791 PLN/ha. The share of the direct subsidy in that surplus was $21.4 \%$. In the analyzed year, a farm cultivated 217 ha, which constituted $12.8 \%$ of the sowing structure.

Chemical pest control in rape cultivation needs to be conducted reasonably and according to the Good Practices in Plant Protection.

\section{CONCLUSIONS}

The conducted research on profitability of pest control in rape cultivation have allowed the following conclusions to be made:

1. The area of rape cultivation in Poland increased from 624,000 ha in 2006 to 810,000 in 2009.

2. Harmfulness of pests in rape cultivation in the country was diversified and the most harm was observed in the south-western and northern provinces.

3. Selling prices for rape in the analyzed years increased significantly, from 44.80 PLN/dt to 127.76 PLN/dt.

4. Profitability of a one-time pest control treatment in rape cultivation measured in the cost covering index $\left(E_{1}\right)$, fluctuated between 0.6 to $2.3 \mathrm{dt}$, and the index was the most favorable in the year 2009. The $E_{1}$ index was also bigger for the Fastac 100 EC chemical.

5. Approximate profitability index $\left(E_{2}\right)$ specifies the percentage of yield that needs to be allocated to cover the costs of chemical pest control and depends on the chemical applied and the number of treatments. The approximate profitability index $\left(\mathrm{E}_{2}\right)$ fluctuated between $2.06 \%$ to $7.62 \%$. More favorable indexes were observed in regions of big rape yields. 


\section{REFERENCES}

Food and Agriculture Organization (FAO). 1997. State of Word's Forest 1997. Food and Agriculture Organization of the United Nations, Words and Publications, Oxford, UK, 30 pp.

Golinowska M. 1991. Effectiveness of protecting winter rape against pests and weeds. Sci. J. 101, p. 66.

Golinowska M. 1994. Factors influencing the yield of rape in production conditions. Sci. J. 59: 71-88.

Golinowska M. 2002. Effectiveness of plant protection on individual farms in south-western Poland. Sci. J. 433, p 199.

Jajor E., Korbas M., Kozłowski J., Mrówczyński M., Pruszyński G., Wachowiak H., Walczak F., Węgorek P. 2008. Poradnik sygnalizatora ochrony rzepaku. [Guide for Rape Protection Signaling Device] (eds. Walczak F.). Institute of Plant Protection - National Research Institute, Poznań, 153 pp.

Kelm M. 2000. Uwarunkowania Występowania i Szkodliwości Roślinożernej Entomofauny Rzepaku Ozimego na Dolnym Ślasku. [Conditions for Occurrence and Harmfulness of Herbivorous Entomofauna in Winter Rape in Lower Silesia]. AR Wrocław, 145, pp.

Kucharski K., Golinowska M. 2009. Efektywność ekonomiczna zabiegów ochrony roślin w systemie uprawy bezpłużnej. [Economic effectiveness of plant protection treatments within a no-till farming system]. Prog. Plant Prot./Post. Ochr. Roślin 49 (2): 484-492.

MrówczyńskI M. 2003. Studium nad Doskonaleniem Ochrony Rzepaku Ozimego przed Szkodnikami. [Research on Improving the Protection of Winter Rape Against Pests]. Sci. thesis., Inst. Plant Prot., Poznań, 61 pp.

Mrówczyński M., Pruszyński S. 2006. Integrowana Produkcja Rzepaku. [Integrated Rape Production]. Inst. Plant Prot., Poznań, 84 pp.
Pałosz T. 1988. Ekonomiczne i Ekologiczne i Agrotechniczne Elementy Doskonalenia Programów Zwalczania Szkodników Rzepaku Ozimego. [Economic, Ecological and Agrotechnological Elements of Improving Programs for Pest Control in Winter Rape]. Inst. Plant Prot., Poznań, 92 pp.

Rocznik Statystyczny [Statistical Yearbook], 2009. Rocznik Statystyczny 2009, Główny Urząd Statystyczny, Warszawa, 97 pp.

Walczak F. 2006. Choroby i szkodniki roślin przemysłowych. [Diseases and pests of industrial plants - rape]. p. 27-31. In: “Stan Fitosanitarny Roślin w Polsce w roku 2006 i Spodziewane Występowania Agrofagów w 2007 r." [Phytosanitary Condition of Plants in Poland in 2006 and Expected Occurrence of Pests in 2007]. Inst. Plant Prot., Poznań, 95 pp.

Walczak F. 2008. Choroby i Szkodniki Roślin Przemysłowych Rzepak. [Diseases and pests of industrial plants - rape]. p. 31-36. In: "Stan fitosanitarny roślin w Polsce w roku 2007 i spodziewane występowania agrofagów w 2008 r." [Phytosanitary Condition of Plants in Poland in 2007 and Expected Occurrence of Pests in 2008]. Inst. Plant Prot., Poznań, 112 pp.

Walczak F. 2009. Choroby i szkodniki roślin przemysłowych rzepak. [Diseases and pests of industrial plants - rape]. p. 34-40. In: "Stan Fitosanitarny Roślin w Polsce w Roku 2008 i Spodziewane Występowania Agrofagów w 2009 r." [Phytosanitary Condition of Plants in Poland in 2008 and Expected Occurrence of Pests in 2009]. Inst. Plant Prot., Poznań, 112 pp.

Walczak F. 2010. Choroby i szkodniki roślin przemysłowych rzepak. [Diseases and pests of industrial plants - rape]. p. 34-40. In: "Stan Fitosanitarny Roślin w Polsce w Roku 2009 i Spodziewane Występowania Agrofagów w 2010 r." [Phytosanitary Condition of Plants in Poland in 2009 and Expected Occurrence of Pests in 2010]. Inst. Plant Prot., Poznań, 110 pp. 